\title{
Substitution of Norway spruce for Douglas-fir: changes of soil microbial activities as climate change induced shift in species composition - a case study
}

\author{
Vilém Podrázský*, Ivo Kupka, Hana Prknová \\ Czech University of Life Sciences Prague, Faculty of Forestry and Wood Sciences, Kamýcká 129, CZ - 16500 Prague - Suchdol, \\ Czech Republic
}

\begin{abstract}
Douglas-fir (Pseudotsuga menziesii [Mirb.] Franco) is the most common utilized introduced tree species in the temperate zone, planted in many European countries. Also, in the Czech Republic it represents the most planted exotic species as well. Its planted area exceeds 6,000 ha and represents $0.25 \%$ of the forest area of the country. In the last years, this species is supposed as convenient substitution for declining Norway spruce (Picea abies [L.] Karst.) stands under current climatic change (extreme drought, bark beetle outbreak). The changed species composition affects also soil dynamic processes, including litter decomposition and transformation. In the presented study, the respiration rate and nitrification intensity were compared in the stand parts dominated by Norway spruce and Douglas-fir in comparable site conditions ( $410 \mathrm{~m}$ a.s.l., $650 \mathrm{~mm}, 8^{\circ} \mathrm{C}$, gleyic Luvisol, fresh oak-fir site with Oxalis acetosella, age 97 years). Analyses were performed in laboratory conditions by standard methods determining actual (basal) and potential respiration activity and intensity of ammonia and nitrate ion production. Admixture of Douglas-fir considerably intensified decomposition activities (soil respiration) and profoundly increased the nitrification rate in the surface humus and uppermost mineral soil layer - Ah horizon. Increased interest in the Douglas-fir silviculture needs increased care for forest soil dynamics with respect of nitrogen balance.
\end{abstract}

Key words: forest soils; soil microbiology; soil respiration; ammonification; nitrification

Editor: Igor Štefančík

\section{Introduction}

Soil microbial activity is an important indicator of the soil organic matter dynamics. Its role in the site quality indication has been recognized since early history of the modern soil science; it indicates changes in soil dynamics more evidently and early, compared to soil chemical characteristics (Seifert 1957). Among others, the activity of soil micro-organisms results in the formation of differentiated humus forms (Green et al. 1993; Ponge 2003). Decomposition and transformation processes are supported especially by the quality and amount of the litter (above- as well as below-ground) and by root exsudates, determining the composition and activity of soil organism communities (Prescott \& Grayston 2013). The conditions for organic matter dynamics are affected particularly by the species composition of the forest ecosystems and by their age and spatial structure (Augusto et al. 2002). Even the natural disturbances and silvicultural treatments influence the microbial activities of the soils (Svoboda \& Podrázský 2005).
Douglas-fir (Pseudotsuga menziesii [Mirb.] Franco) is a species with high commercial importance in the World as well as in the Europe, widely used in the forest management of many countries. On the contrary, in the Czech Republic it is cultivated only on area, exceeding slightly 6,000 ha, which represents approximately $0.25 \%$ of the stand area (Beran 2018), despite increasing interest of the forestry practice. Its potential is much higher in the country on the other hand. Only its proper use as the site improving and stabilizing tree species accordingly to recent legislation could result in an area increase to some $5.7-6.2 \%$ of the forested lands, which accounts for 149,616 to 163,713 ha and 25.3 - 28.6 mil. EUR yr ${ }^{-1}$ of value increment (Pulkrab et al. 2014). In this study mentioned, the cultivation of Douglas-fir in monocultures, prevailing in the Western Europe, is excluded. The production potential of Douglas-fir was documented substantially to consider its use in the future, also its environmental effects were partly analyzed; for summary see e.g. Martiník (2003), Kubeček et al. (2014) and

*Corresponding author.Vilém Podrázský,e-mail:podrazsky@fld.czu.cz 
Mondek \& Baláš (2019), in other countries e.g. Augusto et al. (2002), Budde (2006) and Riedl et al. (2019). The selection of proper provenances is of great importance (Beran 1993, 1995; Eilmann et al. 2013; Petkova et al. 2014; Popov 2014; Kšír et al. 2015, 2019), as well as the corresponding seed material management (Martiník \& Palátová 2012; Kuneš et al. 2017). Also, the natural regeneration of this species is very successful in convenient conditions (Bušina 2007; Kantor et al. 2010). On the other hand, Douglas-fir is suitable for afforestation of agricultural landscapes (Cukor et al. 2017a).

Douglas-fir has been planted at the territory of the School Training Forest Kostelec nad Černými lesy since 1880 , occupying the area around 10.5 ha (Hart et al. $2010)$; its production was analyzed here in some cases (Tauchman et al. 2010). On the contrary, some publications indicate certain risk for the nitrogen dynamics in forest ecosystems. Douglas-fir litter dynamics resulted in some cases in the increased nitrogen mineralization, especially nitrification, and the danger of nitrate leaching can be expected (e.g. Zeller et al. 2010). Despite this indication, Douglas-fir is supposed to be a very convenient substitution for Norway spruce at lower altitudes (Temperli et al. 2012, Podrázský et al. 2012), especially under ongoing climatic change (Allen et al. 2010; Vacek et al. 2016; Šimůnek et. al. 2019) causing large-scale spruce decline in Czech Republic (Vacek et al. 2019a; Toth et al. 2020). Douglas-fir is more tolerant to extreme droughts than Norway spruce (Vitali et al. 2017). Moreover, spruce sensitivity to extreme climatic events was also documented in the last decades in others studies compared to other tree species (Králíček et al. 2017; Vacek et al. 2019c; Vančura et al. 2020). In relation to climatic change, Douglas-fir plays important role in carbon sequestration in soils (Antisari et al. 2015; Cukor et al. 2017b).

Aim of the presented study is the comparison of the respiration, ammonification and nitrification activities under Douglas-fir and Norway spruce at comparable site. Two hypotheses were postulated:

1) Douglas-fir is capable of producing litter, which is more easily decomposable compared to Norway spruce; it is supposed to be indicated by higher respiration activity of soil microbes in the upper soil layers,

2) Humus forms developed under Douglas-fir dominance show more intense nitrogen dynamics, manifesting itself especially with high nitrification potential.

\section{Material and methods}

The study area is typical for relatively large areas of the Central Bohemia region, the altitude ranges between $350-450 \mathrm{~m}$, the average annual temperature $7.5-$ $8.5^{\circ} \mathrm{C}$, precipitation $550-650 \mathrm{~mm}$. The study site is located in a stand on the territory of the School Training Forest Kostelec nad Černými lesy. Sites are acid to fresh, soils are Luvisols and Luvic Cambisols, $3^{\text {rd }}-4^{\text {th }}$ vegetation altitudinal zone. In the studied stand $(410 \mathrm{~m}$ a.s.l., $650 \mathrm{~mm}, 8^{\circ} \mathrm{C}$, gleyic Luvisol, Forest Site group $4 \mathrm{O} 1-$ fresh oak-fir site with Oxalis acetosella-Viewegh (2003), age 97 years) the standing volume accounted for $830-$ $1030 \mathrm{~m}^{3}$ per ha, depending on the Douglas fir share (14 $-30 \%$ Nr. of trees, $32.4-42.4 \%$ of basal area, 36.6 $58.3 \%$ of stand volume). Natural regeneration occurs after chemical weed control reaching 16,000 - 31,000 trees per ha. Seedlings disappear at older age in the relatively dark stand (Hart et al. 2010; Remeš et al. 2010).

Microbiological soil characteristics were studied in the same stand parts, where the soil chemistry was evaluated before (see Ulbrichová et al. 2014). Soil samples were taken Nov 272011 and processed using standard methods (see Svoboda \& Podrázský 2005). Soils were sampled in pure larger stand parts with dominance of both Norway spruce and Douglas-fir. Under each species, two bulk samples from $\mathrm{F}_{2}+\mathrm{H}$ and $\mathrm{Ah}$ horizons were taken, each bulk sample from 5 particular sites (Table 1 ). From each bulk sample 4 subsamples were separated for any analysis in the laboratory described below.

Table 1. Bulk samples taken in the stands of Douglas-fir and Norway spruce.

\begin{tabular}{lcccc}
\hline $\begin{array}{l}\text { Species } \\
\text { Horizon }\end{array}$ & Douglas-fir & Norway spruce & Douglas-fir & Norway spruce \\
\hline $\mathrm{F}_{2}+\mathrm{H}$ & $\mathrm{G} 1$ & $\mathrm{G} 3$ & $\mathrm{G} 5$ & $\mathrm{G} 7$ \\
$\mathrm{Ah}$ & $\mathrm{G} 2$ & $\mathrm{G} 4$ & $\mathrm{G} 6$ & $\mathrm{G} 8$ \\
\hline
\end{tabular}

Analyses were done in the Laboratory Tomáš, located at FGMRI, Research Station Opočno. In particular samples the following analyses were performed:

Biological activity actual: from each bulk sample, 4 subsamples of $50 \mathrm{~g}$ of air-dried soil (mineral horizon) or $25 \mathrm{~g}$ (surface humus horizon) were placed in 1 liter flask, watered by determined amount of distilled water. In the flask, a cup with $25 \mathrm{ml}$ of $0.1 \mathrm{~N} \mathrm{NaOH}$ was located, capturing respired $\mathrm{CO}_{2}$. In the next 5 days, after each 24 $\mathrm{h}$ period the diluted $\mathrm{CO}_{2}$ was analyzed by titration.

Biological activity potential: half amount of both substrates was sprayed with $12.5 \%$ glucose solution in the amount of $4 \mathrm{ml}$ for $50 \mathrm{~g}$ of substrate. Incubation is $24 \mathrm{~h}$ at $25^{\circ} \mathrm{C}$. In both cases, the amount of captured $\mathrm{CO}_{2}$ is determined by titration.

Nitrification: the weight of substrate samples is $50 \mathrm{~g}$ (mineral soil) or $25 \mathrm{~g}$ (humus horizon), moisturized by distilled water and incubated in the thermostatic chamber 14 days at $25^{\circ} \mathrm{C}$. The space inside was saturated by vapor all the time of incubation. The same amount of substrates was stored in the freezer for control measurement. The incubated samples as well as the control sample are leached by potassium sulphate, filtered, and the ammonia and nitrate nitrogen is determined after that. The ammonia ions are determined in the solution of sulphuric acid colorimetrically with Nessler's solution, the nitrate nitrogen is determined directly by nitrate-electrode.

The SW Statistica 10.0 (Statsoft, Tulsa) was used for data processing, the non-parametric test KolmogorovSmirnov was applied for data analysis. 


\section{Results}

Results indicated highly significant differences in the soil respiration activity, both actual and potential (Table 2). The substrates from the Douglas-fir stand parts show significantly faster decomposition and the microbial communities are much more active in $\mathrm{F}_{2}+\mathrm{H}$ and $\mathrm{Ah}$ horizons compared to Norway spruce.

Table 2. Respiration activity actual (AA) and potential (PA) in the stand of Douglas-fir and Norway spruce in the horizons $\mathrm{F}_{2}+\mathrm{H}$ and $\mathrm{Ah}\left(\mathrm{mg} \mathrm{CO}_{2} / 100 \mathrm{~g}\right.$ dry soil per $\left.24 \mathrm{~h}\right)$.

\begin{tabular}{lcccc}
\hline Species & Douglas-fir & Norway spruce & Douglas-fir & Norway spruce \\
Horizon & \multicolumn{2}{c}{$\mathrm{F}_{2}+\mathrm{H}$} & \multicolumn{2}{c}{$\mathrm{Ah}$} \\
\hline AA 1.day & $199.0720 \mathrm{a}$ & $95.8345 \mathrm{~b}$ & $22.5567 \mathrm{a}$ & $6.07858 \mathrm{~b}$ \\
AA 2.day & $162.3819 \mathrm{a}$ & $80.7918 \mathrm{~b}$ & $14.5320 \mathrm{a}$ & $2.86152 \mathrm{~b}$ \\
AA 3.day & $140.1887 \mathrm{a}$ & $62.8726 \mathrm{~b}$ & $15.6585 \mathrm{a}$ & $4.52673 \mathrm{~b}$ \\
AA 4.day & $137.0985 \mathrm{a}$ & $57.4448 \mathrm{~b}$ & $13.2878 \mathrm{a}$ & $3.13458 \mathrm{~b}$ \\
AA 5.day & $153.4415 \mathrm{a}$ & $76.3180 \mathrm{~b}$ & $12.8356 \mathrm{a}$ & $8.43414 \mathrm{a}$ \\
PA 1.day & $541.1018 \mathrm{a}$ & $271.4150 \mathrm{~b}$ & $108.4001 \mathrm{a}$ & $29.91750 \mathrm{~b}$ \\
\hline Notes: Different indexes indicate statistically significant differences at $(\mathrm{p}<0.001)$ between cor-
\end{tabular}

responding horizons; $\mathrm{AA}$ - actual respiration activity, $\mathrm{PA}$ - potential respiration activity.

Similarly, the nitrogen dynamics is more intense under Douglas-fir, compared to Norway spruce (Table $3)$. The soil moisture values were comparable in both stand parts at the time of sampling. In the holorganic layer, the contents of soil ammonia cations were lower in the stand parts under Douglas-fir before incubation, this difference was not significant. Contents of the nitrate anions were comparable. Both nitrogen forms showed lower content values in organomineral horizons (Ah) under spruce before incubation, it represented roughly one-half in the case of ammonia nitrogen, one-tenth in the case of the nitrate one.
These differences changed after incubation. Under spruce, the increased ammonification intensity led to increase of ammonia cations in both studied horizons. In addition, nitrification was supported, the contents of nitrate nitrogen was cca doubled after the period of incubation.

Different situation was documented under Douglasfir stand parts. The content of ammonia cations decreased cca by $50 \%$ in both studied horizons, on the contrary, the content of nitrate nitrogen multiplied during the incubation. The differences in the content of nitrogen forms under particular tree species after incubation are shown in the Fig. $1-2$. The case study confirmed high potential of Douglas-fir compared to Norway spruce to support soil microbial activity resulting in potential carbon and nitrogen mineralization.

\section{Discussion}

The obtained results confirmed both hypotheses formulated, i.e. significant increase of respiration as well as of nitrification activity in the humus forms under Douglasfir after incubation. Faster litter decomposition, mineralization and higher activity of microbial communities can be supposed due to presence of Douglas-fir compared to Norway spruce.

The microbial communities are determined especially by environmental conditions (temperature, soil moisture, geology - bedrock) primarily, secondary effects were detected for tree species (litter), as documented by Augusto et al. (2002) and Brockett et al. (2012). The

Table 3. Soil nitrogen dynamics in the soil substrates under Douglas-fir and under Norway spruce.

\begin{tabular}{|c|c|c|c|c|c|c|}
\hline \multirow{2}{*}{$\begin{array}{l}\text { Species } \\
\text { Horizon }\end{array}$} & & Soil moisture & $\mathrm{N}-\mathrm{NH}_{4}^{+}$before incubation & $\mathrm{N}-\mathrm{NH}_{4}^{+}$after incubation & $\mathrm{N}-\mathrm{NO}_{3}^{-}$before incubation & $\mathrm{N}-\mathrm{NO}_{3}{ }^{-}$after incubation \\
\hline & & $\%$ & \multicolumn{4}{|c|}{$\begin{array}{c}\mathrm{mg} \mathrm{kg}^{-1} \\
\text { D.M. }\end{array}$} \\
\hline D.-fir & $\mathrm{F}_{2}+\mathrm{H}$ & 45 & 82.8 & $37.4 \mathrm{a}$ & 24.6 & $101.0 \mathrm{a}$ \\
\hline D.-fir & Âh & 18 & 43.4 & $28.1 \mathrm{a}$ & 11.4 & $29.0 \mathrm{a}$ \\
\hline N. spruce & $\mathrm{F}+\mathrm{H}$ & 42 & 101.2 & $134.0 \mathrm{~b}$ & 21.1 & $47.0 \mathrm{~b}$ \\
\hline N. spruce & Ah & 16 & 26.0 & $46.4 \mathrm{a}$ & 1.2 & $3.3 \mathrm{~b}$ \\
\hline
\end{tabular}
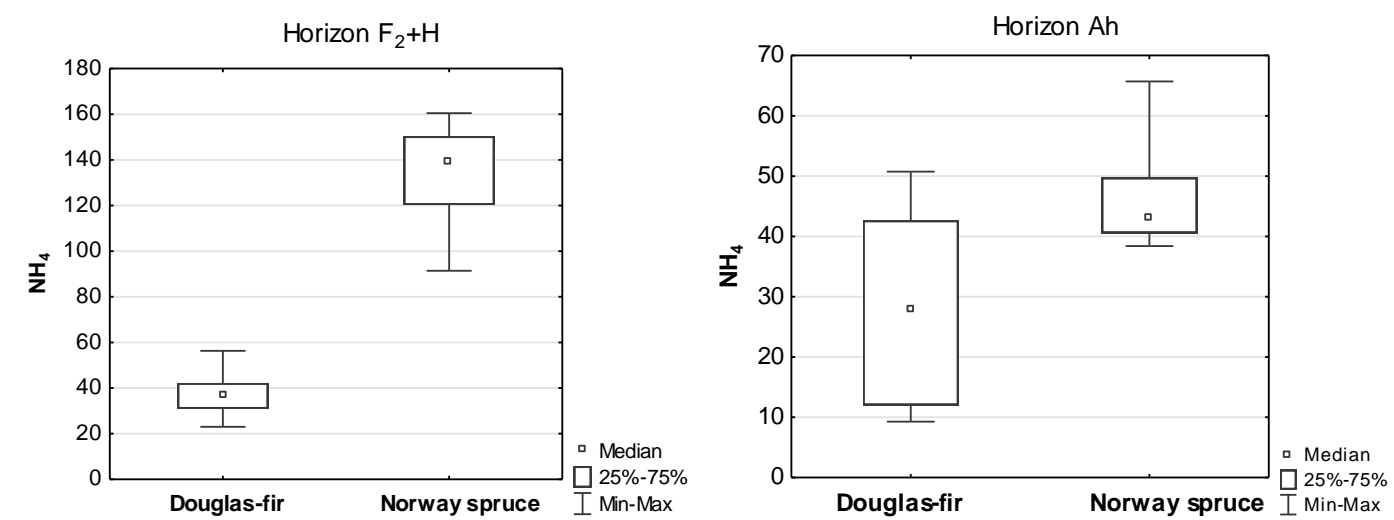

Fig. 1. Contents of ammonia nitrogen in the horizon $\mathrm{F}_{2}+\mathrm{H}$ (left) and Ah (right) under Douglas-fir and Norway spruce after incubation $\left(\mathrm{mg} \mathrm{kg}^{-1}\right)$. 

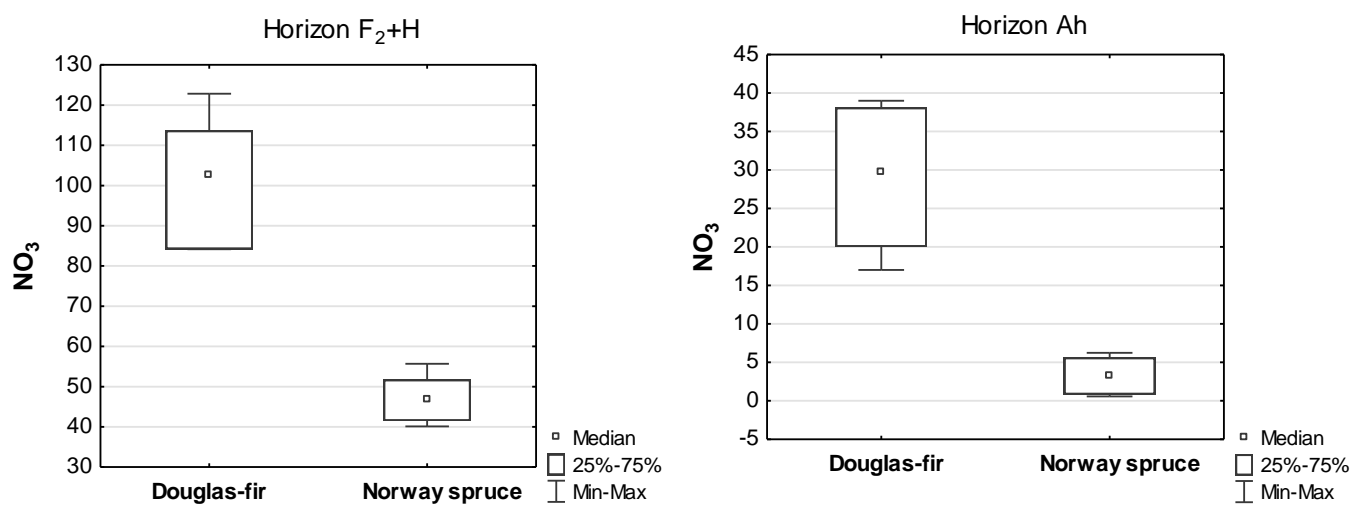

Fig. 2. Contents of nitrate nitrogen in the horizon $\mathrm{F}_{2}+\mathrm{H}$ (left) and Ah (right) under Douglas-fir and Norway spruce after incubation $\left(\mathrm{mg} \mathrm{kg}^{-1}\right)$.

latter authors detected also higher $\mathrm{N}$-availability in the Douglas-fir dominated tree communities. In our case, environmental conditions determined by local microclimate were the same and the soil moisture was similar too (Table 3). The differences in the soil characteristics were, therefore, a result of different tree species (litter) effects dominantly.

Changes of tree species composition of forest ecosystems offer rapid modification of the soil organic matter turnover and SOM quality (Antisari et al. 2015). These authors described changes in the carbon and nutrient cycling as well as in the microbial activity as they compared native European beech with Douglas-fir stands growing at higher elevations (1 $000-1300 \mathrm{~m}$ a.s.l.) of the Tuscanian Apeninnes. Antisari et al (2015) concluded also higher basal respiration in the upper mineral soil under Douglas-fir compared to beech, whereas slower $\mathrm{C}$-mineralization and $\mathrm{C}$-turnover were shown on the other side, resulting in higher $\mathrm{C}$-accumulation under Douglas-fir. They ascribed this fact to the more recalcitrant and hydrophobic composition than that of the epipedon under beech. Less favorable humus forms under Douglas-fir compared to beech reported Martiník (2003) and Menšík et al. (2009). Similarly, increasing C-accumulation and soil stabilization with ageing (80 -100 years) of Douglas-fir described in the same Italian region Antisari et al. (2018). In older stands of this species, lower availability of nitrogen can be observed due to increasing $\mathrm{C} / \mathrm{N}$ ratio. From this we can concluded, that long term $\mathrm{N}$-mobilisation due to increased $\mathrm{N}$-mineralisation and fixation in biomass can lead to $\mathrm{N}$-shortage in the ecosystem.

Prietzel \& Bachmann (2012) studied the changes in humus form status and sequestration of SOM (OC organic carbon) and $\mathrm{N}$ in the set of stands, documenting shift from Norway spruce and Scots pine towards Douglas-fir and European beech forests. They also confirmed in most cases significant decrease of surface humus $\mathrm{C} / \mathrm{N}$ ratio in the order spruce, pine $>$ mixture of spruce or pine with Douglas-fir $>$ Douglas-fir $>$ beech. Forest floor OC and $\mathrm{N}$ stocks decreased in the same order. Trends in the mineral soil were opposite, as for OC stock and especially in the mineral N amount. Mixture of Douglas-fir and spruce was documented as an effectively increasing $\mathrm{C}$ and $\mathrm{N}$ sequestration; the benefits of mixtures are also in the $\mathrm{CO}_{2}$ fixation. Mixed forest stands are a very good tool for forest stability enhancement (Mondek et al. 2019) and for high quality timber supply (Palátová et al. 2017; Riedl et al. 2019). Higher nitrification under Douglas-fir compared to Norway spruce documented also Malchair \& Carnol (2009). On the contrary, humus form microbial activity was lower in Douglas-fir compared to broadleaved (birch) stands (Welke \& Hope (2005). The proper stand composition and management is a vital prerequisite for sufficient stand nutrition. Mixing of tree species is important also in the case of Douglas-fir absence in the stand mixture in relation to higher diversity, stability and also production compared to monospecific forest stands (Pretszch et. al. 2010; Vacek et al. 2019b; Mikulenka et al. 2020; Prokůpková 2020). This is much more important while this species is included (Šrámek et al. 2019). Increased interest in silviculture of Douglas-fir has to be connected with establishing of site corresponding species mixture. Under these conditions, Douglas-fir can be a proper substitution for site-degrading conifers in the period of climate change (Mondek \& Baláš 2019).

\section{Conclusions}

The results confirmed differences in the litter decomposition and mineralization activities between stand parts dominated by Norway spruce and Douglas-fir. It can be supposed, that admixture of Douglas-fir will accelerate and promote microbial activities, resulting in faster litter decomposition (increased potential and actual respiration activity) and more pronounced nitrogen dynamics (nitrification). These trends can explain lower surface humus amount and its more favorable pedochemical characteristics. Proper use of this knowledge demands cultivation of Douglas-fir in site-corresponding mix- 
tures of tree species. Substitution of coniferous stands with site-corresponding mixtures is supposed to improve forest stability and vitality in the changing environmental conditions.

\section{Acknowledgements}

The paper originated as a part of reseach project $N A Z V$ QK1920328 "Complex solution of forest restoration and silvicultural management in regions with fast large-scale forest decline".

\section{References}

Allen, C. D., Macalady, A. K., Chenchouni, H., Bachelet, D., McDowell, N., Vennetier, M. et al., 2010:A global overview of drought and heat-induced tree mortality reveals emerging climate change risks for forests. Forest Ecology and Management, 259:660-684.

Antisari, L. V., Falsone, G., Carbone, S., Marinari, S., Vianello, G., 2015: Douglas-fir reforestation in North Apennine (Italy): Performance on soil carbon sequestration, nutrients stock and microbial activity. Applied Soil Ecology, 86:82-90.

Antisari, L. V., Papp, R., Vianello, G., Marinari, S., 2018: Effects of Douglas fir stand age on soil chemical properties, nutrient dynamics, and enzyme activity: a case study in Northern Appenines, Italy. Forests, 9:641.

Augusto, L., Ranger, J., Binkley, D., Rothe, A., 2002: Impact of several common tree species of European temperate forests on soil fertility. Annales of Forest Science, 59:233-253.

Beran, F., 1993: Fenotypová proměnlivost a růst douglasky tisolisté na školním polesí Hůrka (SLŠ Písek). Zprávy lesnického výzkumu, 38:5-15.

Beran, F., 1995: Dosavadní výsledky provenienčního výzkumu douglasky tisolisté v ČR. Zprávy lesnického výzkumu, 40:7-13.

Beran, F., 2018: Introdukované dřeviny v lesním hospodářství ČR - Přehled. In: Vacek, Z., Podrázský, V. (eds.): Introdukované dřeviny jako součást českého lesnictví, ČLS, Kostelec nad Černými lesy, p. 7-16.

Beran, F., Dostál, J., Fulín, M., 2019: Vyhodnocení nejstarších provenienčních ploch s douglaskou tisolistou v České republice. Zprávy lesnického výzkumu, 64:65-76.

Brockett, B. F. T., Prescott, C. E., Grayston, S. J., 2012: Soil moisture is the major factor influencing microbial community structure and enzyme activities across seven geoclimatic zones in western Canada. Soil Biology \& Biochemistry, 44: 9-20.

Budde, S., 2006: Auswirkungen des Douglasienanbaus auf die Bodenvegetation im nordwestdeutschen Tiefland. Göttingen, Faculty of Forest Sciences and Forest Ecology, Georg-August-Universität Göttingen, Cuvillier Verlag, 146 p.
Bušina, F., 2007: Natural regeneration of Douglas fir (Pseudotsuga menziesii [Mirb.] Franco) in forest stands of Training Forest District Hůrky, Higher Forestry School and Secondary Forestry School in Písek. Journal of Forest Science, 53: 20-34

Cukor, J., Linhart, L., Vacek, Z., Baláš, M., Linda, R., 2017a: The effects of Alginite fertilization on selected tree species seedlings performance on afforested agricultural lands. Central European Forestry Journal, 63:48-56.

Cukor, J., Vacek, Z., Linda, R., Bílek, L., 2017b: Carbon sequestration in soil following afforestation of former agricultural land in the Czech Republic. Central European Forestry Journal, 63:97-104.

Eilmann, B., de Vries, S. M. G., den Ouden, J., Mohren, G. M. J., Sauren, P., Sass-Klaassen, U., 2013: Origin matters! Difference in drought tolerance and productivity of coastal Douglas-fir (Pseudotsuga menziesii [Mirb.]) provenances. Forest Ecology and Management, 302:133-143.

Green, R. N., Trowbridge, R. L., Klinka, K., 1993: Towards a taxonomic classification of humus forms. Forest Science, 39:1-49.

Hart, V., Hartová, M., Tauchman, P., 2010: Analysis of herbicide effects on Douglas fir (Pseudotsuga menziesii [Mirb.] Franco) natural regeneration. Journal of Forest Science, 56:209-217.

Kantor, P., Bušina, F., Knott, R., 2010: Postavení douglasky tisolisté (Pseudotsuga menziesii [Mirb.] Franco) a její přirozená obnova na školním polesí Hůrky středních lesnických škol Písek. Zprávy lesnického výzkumu, 55:251-263.

Králíček, I., Vacek, Z., Vacek, S., Remeš, J., Bulušek, D., Král, J. et al., 2017: Dynamics and structure of mountain autochthonous spruce-beech forests: impact of hilltop phenomenon, air pollutants and climate. Dendrobiology, 77:119-137.

Kšír, J., Beran, F., Podrázský, V., Novotný, P., Dostál, J., Kubeček, J., 2015: Výsledky hodnocení mezinárodní provenienční plochy s douglaskou tisolistou (Pseudotsuga menziesii [Mirb.] Franco) na lokalitě Hůrky v Jižních Čechách ve věku 44 let. Zprávy lesnického výzkumu, 60:104-114.

Kubeček, J., Štefančík, I., Podrázský, V., Longauer, R., 2014: Výsledky výzkumu douglasky tisolisté (Pseudotsuga menziesii [Mirb.] Franco) v České republice a na Slovensku - přehled. Lesnícky časopis - Forestry Journal, 60:120-129.

Kuneš, I., Baláš, M., Linda, R., Gallo, J., Nováková, O., 2017: Effects of brassinosteroid application on seed germination of Norway spruce, Scots pine, Douglas fir and English oak. IForest, 10:121-127.

Malchair, S., Carnol, M., 2009: Microbial biomass and $\mathrm{C}$ and $\mathrm{N}$ transformations in forest floors under European beech, sessile oak, Norway spruce and Douglas-fir at four temperate forest sites. Soil Biology \& Biochemistry, 41:831-839. 
Martiník, A., 2003: Possibilities of growing Douglas fir (Pseudotsuga menziesii [Mirb.] Franco) in the conception of sustainable forest management. Ekológia (Bratislava), 22(Suppl. 3):136-146.

Martiník, A., Palátová, E., 2012: Je předosevní příprava osiva douglasky tisolisté nezbytná? Zprávy lesnického výzkumu, 57:47-55.

Menšík, L., Kulhavý, J., Kantor, P., Remeš, M., 2009: Humus conditions of stands with the different proportion of Douglas fir in training forest district Hůrky and the Krrtiny Forest Training Enterprise. Journal of Forest Sciences, 55:345-356.

Mikulenka, P., Prokůpková, A., Vacek, Z., Vacek, S., Bulušek, D., Simon, J. et al., 2020: Effect of climate and air pollution on radial growth of mixed forests: Abies alba (Mill.) vs. Picea abies (L.) Karst. Central European Forestry Journal, 66:23-36.

Mondek, J., Baláš, M., 2019: Douglas-fir (Pseudotsuga menziesii [Mirb.] Franco) and its role in the Czech forests. Journal of Forest Science, 65:41-50.

Palátová, P., Dudík, R., Hušbauer, J., 2017:Czech Wood and Potential of its Consumption in the Czech Republic. In: Dudík, R. (ed.): More Wood, Better Management, Increasing Effectiveness: Starting Points and Perspective. Prague, WoodEMA, i.a., p. 33-37.

Petkova, K., Goergieva, M., Uzunov, M., 2014: Investigation of Douglas-fir provenance test in North-Western Bulgaria at the age of 24 years. Journal of Forest Science, 60:288-296.

Podrázský V., Remeš J., Sloup R., Pulkrab K., Novotná S., 2016: Douglas-fir - partial substitution for declining conifer timber supply - review of Czech data. Wood Research, 61:525-530.

Popov, E. B., 2014: Results of 20 years old Douglas-fir provenance experiment established on the northern slopes of Rila Mountain in Bulgaria. Journal of Forest Science, 60:394-399.

Ponge, J. F., 2003: Humus forms in terrestrial ecosystems: A framework to biodiversity. Soil Biology and Biochemistry, 35:935-945.

Prescott, C. E., Grayston, S. J., 2013: Tree species influence on microbial communities in litter and soil: $\mathrm{Cur}$ rent knowledge and research needs. Forest Ecology and Management, 309:19-27.

Pretzsch, H., Block, J., Dieler, J., Dong, P. H., Kohnle, U., Nagel, J. et al., 2010: Comparison between the productivity of pure and mixed stands of Norway spruce and European beech along an ecological gradient. Annals of Forest Science, 67:712.

Prokůpková, A., 2020: Dynamics of mixed lowland forests in Central Bohemia over a 20 -year period. Journal of Forest Science, 66: 49-62.

Pulkrab, K., Sloup, M., Zeman, M., 2014: Economic impact of Douglas-fir (Pseudotsuga menziesii [Mirb.] Franco) production in the Czech Republic. Journal of Forest Science, 60:297-306.
Remeš, J., Pulkrab, K., Tauchman, P., 2010: Produkční a ekonomický potenciál douglasky tisolisté na vybrané lokalitě ŠLP Kostelec nad Černými lesy In: Prknová, H. (ed.): Aktuality v pěstování introdukovaných dřevin. Praha, Česká zemědělská univerzita v Praze, p. 68-69.

Riedl, M., Jarský, V., Palátová, P., Sloup, R., 2019: The Challenges of the Forestry Sector Communication Based on an Analysis of Research Studies in the Czech Republic. Forests, 10:935.

Seifert, J., 1957:Vlivjedlového porostu na biologický stav půdy. Folia Microbiologica, 2:234-237.

Svoboda, M., Podrázský, V., 2005: Forest decline and pedobiological characteristics of humus forms in the Šumava National Park. Journal of Forest Science, 51:141-146.

Šimůnek, V., Vacek, Z., Vacek, S., Králíček, I., Vančura, K., 2019: Growth variability of European beech (Fagus sylvatica L.) natural forests: Dendroclimatic study from Krkonoše National Park. Central European Forestry Journal, 65:92-102.

Šrámek, V., Fadrhonsová, V., Neudertová Hellebrandová, K., 2019: Nutrition of Douglas-fir in four different regions of the Czech Republic. Journal of Forest Science, 65:1-8.

Tauchman, P., Hart, V., Remeš, J., 2010: Srovnání produkce porostu douglasky tisolisté (Pseudotsuga menziesii [Mirbel] Franco) s porostem smrku ztepilého (Picea abies L. Karst.) a stanovištně původním smíšeným porostem středního věku na území ŠLPv Kostelci nad Černými lesy. Zprávy lesnického výzkumu, 55:187-194.

Temperli, C., Bugmann, H., Elkin, C., 2012: Adaptive management for competing forest goods and services under climate change. Ecological Application, 22: 2065-2077.

Toth, D., Maitah, M., Maitah, K., Jarolínová, V., 2020: The Impacts of Calamity Logging on the evelopment of Spruce Wood Prices in Czech Forestry. Forests, 11:283.

Ulbrichová, I., Kupka, I., Podrázský, V., Kubeček, J., Fulín, M., 2014: Douglaska jako meliorační a zpevňující dřevina. Zprávy lesnického výzkumu, 59:72-78.

Vacek, S., Vacek, Z., Bílek, L., Simon, J., Remeš, J., Hůnová, I., Král, J., Putalová, T., Mikeska, M., 2016: Structure, regeneration and growth of Scots pine (Pinus sylvestris L.) stands with respect to changing climate and environmental pollution. Silva Fennica, 50:1564.

Vacek, S., Prokůpková, A., Vacek, Z., Bulušek, D., Šimůnek, V., Králíček, I. et al., 2019a: Growth response of mixed beech forests to climate change, various management and game pressure in Central Europe. Journal of Forest Science, 65:331-345.

Vacek, Z., Vacek, S., Slanař, J., Bílek, L., Bulušek, D., Štefančík, I. et al., 2019b: Adaption of Norway spruce and European beech forests under climate change: from resistance to close-to-nature silviculture. Central European Forestry Journal, 65:129-144. 
Vacek, S., Vacek, Z., Ulbrichová, I., Bulušek, D., Prokupková, A., Král, J., Vančura, K., 2019c: Biodiversity dynamics of differently managed lowland forests left to spontaneous development in Central Europe. Austrian Journal of Forest Science, 136:249-281.

Vančura, K., Prokůpková, A., Bulušek, D., Šimůnek, V., Hájek, V., Králíček, I., 2020: Dynamics of mixed lowland forests in Central Bohemia over a 20-year period. Journal of Forest Science, 66:49-62.

Viewegh, J., 2003: Czech Forest Ecosystem Classification. Journal of Forest Science, 49:74-82.
Vitali, V., Büntgen, U., Bauhus, J., 2017: Silver fir and Douglas fir are more tolerant to extreme droughts than Norway spruce in south-western Germany. Global Change Biology, 23:5108-5119.

Welke, S. D., Hope, G. D., 2005: Influences of stand composition and age on forest floor processes and chemistry in pure and mixed stands of Douglas-fir and paper birch in interior British Columbia. Forest Ecology and Management, 219:29-42.

Zeller, B., Andrianarisoa, S., Jussy, J. H., 2010: Impact of Douglas-fir on the N cycle: Douglas fir promote nitrification? In: Opportunities and risks for Douglas fir in a changing climate. Freiburg, 18-20 October 2010, Berichte Freiburger Forstliche Forschung, 85:11. 